\title{
ЕКОЛОГІЧНО БЕЗПЕЧНА ТЕХНОЛОГІЯ ОДЕРЖАННЯ МІКРОКРИСТАЛІЧНОЇ ЦЕЛЮЛОЗИ 3 ВОЛОКОН КОНОПЕЛЬ
}

\author{
I.B. Трембус, С.В. Сиротюк \\ Національний технічний університет Украйни \\ «Київський політехнічний інститут ім. Ігоря Сікорського» \\ пр. Перемоги, 37, Київ, 03056, Україна \\ e-mail: tivkpi@gmail.com
}

Охорона здоров'я людини та забезпечення іï нагальних потреб в доступних лікарських препаратах є важливою потребою сьогодення. Виробництво пігулок, насамперед, пов'язане 3 використанням допоміжних хімічних речовин, які надають медичним препаратам необхідних властивостей за рахунок наповнення, зв'язування, розпушування [1]. Високий вміст упорядкованої частини целюлози з кристалографічною орієнтацією макромолекул, граничний ступінь кристалічності, висока щільність та питома поверхня мікрокристалічної целюлози (МКЦ) визначають її застосування як зв'язуючої речовини в лікарських препаратах [2].

Традиційною сировиною для виробництва МКЦ є довговолокниста бавовна та деревина хвойних порід деревини [3]. Крім того МКЦ можна отримувати з більш доступної рослинної сировини, насамперед, волокон технічних культур - льону, конопель, кенафу [4]. Використання такої недеревної рослинної сировини (НДРС) привабливе через іiі високу врожайність і щорічну відновлюваність.

На сьогодні відомо різні способи одержання МКЦ: механічний, термомеханічний, хімічний (гідроліз), радіаційно-хімічний, висадження целюлози з розчину у вигляді порошку $[5,6]$. Переважна більшість промислових способів отримання МКЦ грунтується на обробленні рослинної сировини хімічними реагентами з метою максимального видалення 3 неї лігніну, геміцелюлоз, екстрактивних та мінеральних речовин та переведення їх до розчину. Одержана за цими способами порошкоподібна целюлоза відрізняється одна від одної за морфологічною будовою, ступенем кристалічності, ступенем полімеризації (СП), хімічними та гранулометричними властивостями.

Для зменшення екологічного навантаження на навколишнє середовище в останні роки розробляються окисно-органосольвентні способи одержання целюлози, зокрема варіння рослинної сировини пероксикислотами [7]. Варто відзначити, що забезпечення необхідних показників якості МКЦ залежить від кількості і послідовності технологічних стадій одержання МКЦ, виду рослинної сировини та хімічних реагентів для їі одержання.

Метою роботи є розробка ресурсозберігаючої технології одержання із волокон конопель мікрокристалічної целюлози, яка придатна для застосування у фармацевтичній промисловості. 
В якості вихідної сировини для одержання МКЦ використовували волокна технічних конопель (Cannabis sativa), які відсортовувалися від сторонніх включень (костриці, насіння та трави). Волокна подрібнювалися до розмірів $5 \pm 2$ мм і зберігалися в ексикаторах для підтримання постійної вологості та хімічного складу.

Екстракцію рослинної сировини проводили розчином $\mathrm{KOH}$ та $\mathrm{NaOH}$ за їх концентрації 50 та 70 г/л і 30, 40, 50 г/л, відповідно. Гідромодуль процесу становив 10:1. Обробку проводили протягом 20 - 100 хв., за температури $90 \pm 2{ }^{\circ} \mathrm{C}$.

Пероцтове варіння проекстрагованої сировини здійснювали розчином льодяної оцтової кислоти та $35 \%$-вого пероксиду водню за об'ємного співвідношення хімічних реагентів $70: 30 \%$. Процес делігніфікації проводився за гідромодуля $10: 1$, тривалістю від 60 до 240 хв., температури $90 \pm 2{ }^{\circ} \mathrm{C}$. Щоб забезпечити процес варіння, колби були з'єднані зі зворотними холодильниками. Одержану целюлозу промивали до нейтральної реакції, висушували на повітрі для подальших досліджень. Сухість целюлози визначали ваговим методом - сушінням в сушильній шафі за температури $105{ }^{\circ} \mathrm{C}$ до постійної ваги.

Хелатування конопляної целюлози проводили розчином трилону Б концентрацією 10 г/л, за гідромодуля $10: 1, \mathrm{pH}=3$, температури $50 \pm 2{ }^{\circ} \mathrm{C}$, тривалістю 60 хв., концентрації целюлозної маси $4 \%$. Витрати трилону Б становили $20 \%$ від маси абс. сухої. сировини.

Для зниження ступеня полімеризації конопляної целюлози проводили ії гідроліз розчином сульфатної та соляної кислоти за різної її концентрації від 0,5 до 2,0 \%, гідромодуля $15: 1$, температури $90 \pm 2{ }^{\circ} \mathrm{C}$, тривалістю 90 хв. Для одержаної мікрокристалічної целюлози визначали показники якості, які передбачено нормативними документами та у відповідності до методик ТАРPI [8].

3 метою зниження вмісту мінеральних речовин, регулювання в'язкості, досягнення необхідної реакційної здатності проведено екстракцію рослинної сировини розчинами КОН та $\mathrm{NaOH}$ за різної їх концентрації (рис. 1).

Смоли і вищі жирні кислоти, що знаходяться у волокні конопель під дією лугу в процесі обробки нейтралізуються і переходять до розчину у вигляді натрієвих або калієвих солей:

$$
\mathrm{C}_{19} \mathrm{H}_{29} \mathrm{COOH}+\mathrm{KOH} \rightarrow \mathrm{C}_{19} \mathrm{H}_{29} \mathrm{COOK}+\mathrm{H}_{2} \mathrm{O}
$$

Також відбувається переведення до розчину мінеральних речовин, тому зі збільшенням тривалості екстракції та концентрації КОН і $\mathrm{NaOH}$ відбувається зниження зольності одержаних волокнистих напівфабрикатів. Варто відзначити, що за перші 60 хв. екстракції спостерігається значне зниження вмісту мінеральних речовин - від 1,06 до $0,71 \%$.

Експериментальні дослідження (рис. 1) показують, що вміст мінеральних речовин у випадку використання КОН знижується в більшій мірі у порівнянні з NaOH: на 0,52 - 1,09 та 0,23 - 0,88 \%, відповідно. При цьому збільшення концентрації лугу від 50 до 70 г/л малоефективне. Отримані результати знаходяться в межах похибки. Таким чином, рекомендується для отримання із волокон конопель мікрокристалічної целюлози проводити лужну екстракцію рослинної сировини розчином гідроксиду калію концентрацією 50 г/л, протягом 60 хвилин. 


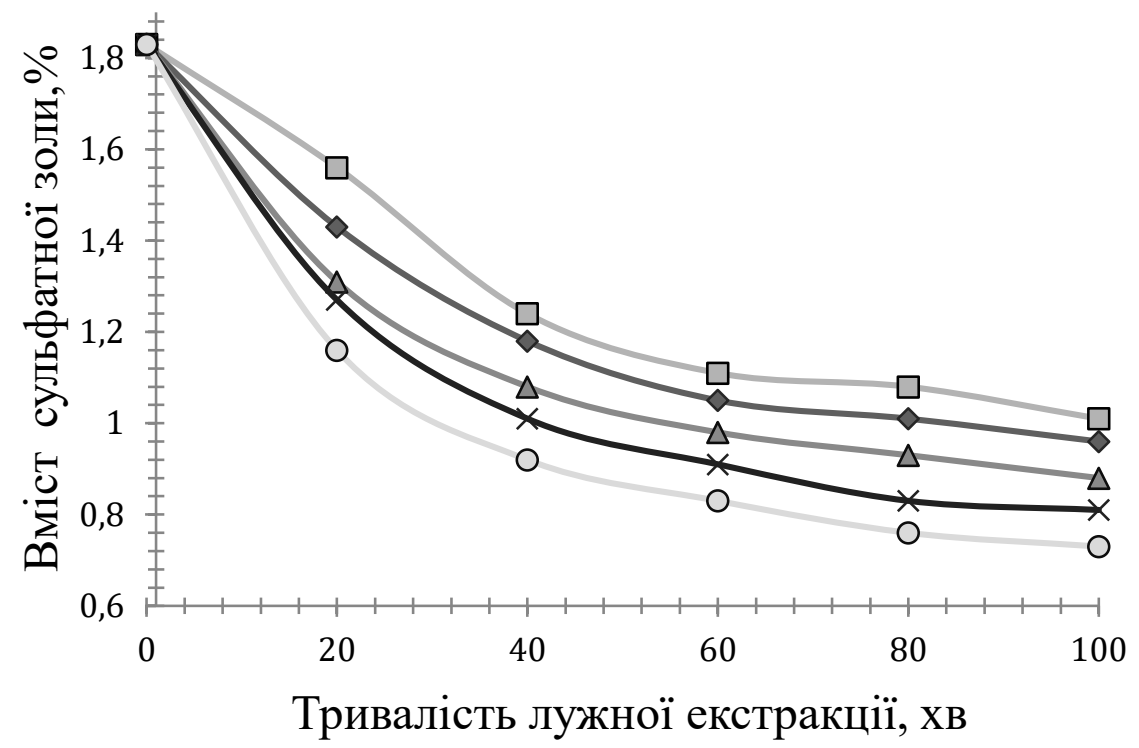

Рисунок. Залежність вмісту сульфатної золи у конопляних ВНФ від тривалості лужної обробки: - $\mathrm{NaOH} 30$ г/л; - NaOH 40 г/л; $\triangle$ - NaOH 50 г/л; $x-\mathrm{KOH} 50$ г/л; ○ - КОН 70 $2 / \pi$

На другій стадії одержання МКЦ проводили процес делігніфікації проекстрагованих волокон конопель розчином пероцтової кислоти. Варто зазначити, що спостерігається різка зміна забарвлення волокон з коричневого на білий. Це зумовлено дією пероцтової кислоти на лігнін. Вона не лише руйнує молекулу лігніну, діючи на ароматичні кільця йогом молекули, а і спричиняє деструкцію хромоформних груп. При цьому руйнівна дія пероцтової кислоти на вуглеводну частину незначна, що сприяє високому виходу целюлози.

Експериментальними дослідженнями встановлено, що оптимальними умовами проведення пероцтової делігніфікації волокон конопель є варіння розчином льодяної оцтової кислоти і 35 \% пероксиду водню у співвідношенні 70:30 об’ємних \%, протягом 240 хв., за ГМ 10:1. В результаті проведення процесу делігніфікації було отриману целюлозу з виходом 84,41 \%, вмістом залишкового лігніну $0,64 \%$, вмістом сульфатної золи $0,28 \%$ від маси проекстрагованих ВНФ.

Для подальшого зниження вмісту мінеральних речовин в отриманій целюлозі проводили процес хелатування 3 використанням розчину трилону Б (двонатрієвої солі етилендиамінтетраоцтової кислоти).

Завдяки утворенню комплексів трилону Б із більшістю катіонів лужноземельних металів зменшується вміст мінеральних речовин, що важливо для подальшого використання МКЦ у фармацевтичній промисловості. Застосування хелатуючої обробки органосольвентної конопляної целюлози дозволило отримати целюлозу із вмістом сульфатної золи 0,21%, що свідчить про необхідність подальшого зменшення вмісту мінеральних речовин у целюлозі.

Для зменшення ступеня полімеризації та видалення аморфної фракції проведено гідроліз

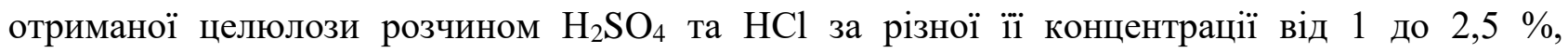


Матеріали XXII Міжнародної науково-практичної конференції «Екологія. Людина. Суспільство» (м. Київ, Україна, 2021 р.)

гідромодуля 15 : 1 і температури $90 \pm 2{ }^{\circ} \mathrm{C}$, протягом 90 хв. Результати досліджень наведено у табл. 1.

Таблиця 1.

Показники якості конопляної МКЦ після процесу гідролізу

\begin{tabular}{|c|c|c|c|c|}
\hline \multirow{2}{*}{ Кислота } & $\begin{array}{c}\text { Концентрація } \\
\text { кислоти, } \%\end{array}$ & Вихід, \% & $\begin{array}{c}\text { Вміст сульфатної } \\
\text { золи, \% }\end{array}$ & $\begin{array}{c}\text { Ступінь } \\
\text { полімеризації }\end{array}$ \\
\hline \multirow{3}{*}{$\mathrm{HCl}$} & 1 & 95,1 & 0,29 & 247 \\
\cline { 2 - 5 } & 1,5 & 93,9 & 0,23 & 187 \\
\cline { 2 - 5 } & 2 & 89,4 & 0,15 & 180 \\
\hline \multirow{3}{*}{$\mathrm{H}_{2} \mathrm{SO}_{4}$} & 2,5 & 86,6 & 0,12 & 217 \\
\cline { 2 - 5 } & 1 & 97,0 & 0,32 & 202 \\
\cline { 2 - 5 } & 1,5 & 93,3 & 0,21 & 187 \\
\cline { 2 - 5 } & 2 & 88,4 & 0,16 & 141 \\
\hline
\end{tabular}

Експериментальні дослідження (табл. 1) свідчать, що обробка целюлози розчином сульфатної і соляної кислот зумовлює подальше зниження вмісту мінеральних речовин, а також ступеня полімеризації конопляної МКЦ. Слід зазначити, що використання сірчаної кислоти в більшій мірі зменшує вміст мінеральної складової в конопляній мікрокристалічній целюлозі, що є основною вимогою згідно Європейської фармакопеї.

Основними хімічними елементами, які характеризують показники зольності в волокнистих напівфабрикатів це метали перемінної валентності: заліза, магнію, марганцю, цинку та кальцію та калію. Було визначено хімічний склад мінеральної складової, яка міститься в волокнистому напівфабрикаті, які було одержано після кожної стадії отримання мікрокристалічної целюлози. Результати досліджень наведено у табл. 2.

Таблиця 2.

Масова частка хімічних елементів в мікрокристалічній целюлозі в залежності від стадій обробки, \%

\begin{tabular}{|c|c|c|c|c|c|}
\hline $\begin{array}{c}\text { Хімічний } \\
\text { елемент }\end{array}$ & $\begin{array}{c}\text { Волокна } \\
\text { конопель }\end{array}$ & $\begin{array}{c}\text { Екстракція } \\
\text { лугом (КОН) }\end{array}$ & $\begin{array}{c}\text { Пероцтове } \\
\text { варіння }\end{array}$ & $\begin{array}{c}\text { Хелатування } \\
\text { (Трилон Б) }\end{array}$ & $\begin{array}{c}\text { Гідроліз } \\
\left(\mathrm{H}_{2} \mathrm{SO}_{4}\right)\end{array}$ \\
\hline${ }^{\mathbf{1 2}} \mathbf{M g}$ & $9,856 \pm 0342$ & $9,654 \pm 1,708$ & $9,103 \pm 1,724$ & - & - \\
\hline${ }^{\mathbf{1 4}} \mathbf{S i}$ & $0,913 \pm 0,235$ & $1,304 \pm 0,235$ & $1,843 \pm 0,235$ & $1,373 \pm 0,710$ & $0,731 \pm 1,081$ \\
\hline${ }^{\mathbf{1 5}} \mathbf{P}$ & $3,956 \pm 0,413$ & $3,794 \pm 0,403$ & $2,148 \pm 0,387$ & $3,050 \pm 1,023$ & $9,194 \pm 1,927$ \\
\hline${ }^{\mathbf{1}} \mathbf{S}$ & - & $1,143 \pm 0,209$ & $1,472 \pm 0,203$ & - & $6,132 \pm 1,237$ \\
\hline${ }^{\mathbf{1 9}} \mathbf{K}$ & $10,051 \pm 0,082$ & $3,459 \pm 0,088$ & $4,571 \pm 0,27$ & - & - \\
\hline${ }^{\mathbf{2 0}} \mathbf{C a}$ & $32,141 \pm 1,721$ & $77,283 \pm 1,521$ & $52,006 \pm 1,059$ & $42,986 \pm 1,371$ & - \\
\hline${ }^{\mathbf{2 5}} \mathbf{M n}$ & $0,912 \pm 0,171$ & $0,859 \pm 0,171$ & - & - & - \\
\hline${ }^{\mathbf{2}} \mathbf{F e}$ & $4,556 \pm 0,174$ & $2,056 \pm 0,181$ & $2,874 \pm 0,183$ & $2,002 \pm 0,633$ & $2,809 \pm 0,491$ \\
\hline${ }^{\mathbf{2}} \mathbf{C u}$ & $0,360 \pm 0,050$ & $0,310 \pm 0,050$ & $0,292 \pm 0,042$ & $0,387 \pm 0,237$ & $0,218 \pm 0,158$ \\
\hline${ }^{\mathbf{3 0}} \mathbf{Z n}$ & $0,691 \pm 0,062$ & $0,688 \pm 0,058$ & $0,487 \pm 0,043$ & $0,201 \pm 0,252$ & $0,712 \pm 0,163$ \\
\hline
\end{tabular}


Як видно 3 даних наведених табл. 2, у процесі перетворення целюлозних волокон спостерігається значне зменшення кількості основних елементів які характеризують показник зольності у волокон конопель, особливо після стадії хелатування. Залишок деяких мінеральних речовин зумовлений наявністю цих металів у водопровідній і дистильованій воді, яка використовуються для промивання волокнистих напівфабрикатів після кожної стадії. На основі проведених досліджень рекомендується для одержання МКЦ використовувати наступну схему обробки волокон конопель: лугування - пероцтове варіння - хелатування гідроліз. Використання запропонованої технології дає змогу одержати МКЦ із показниками якості, що наведені в табл. 3.

Таблиця 3.

\section{Показники якості Свропейської фармакопеї}

\begin{tabular}{|l|c|c|}
\hline \multicolumn{1}{|c|}{ Показники якості } & \multicolumn{1}{|c|}{$\begin{array}{c}\text { Вимоги Європейської } \\
\text { фармакопеї }\end{array}$} & $\begin{array}{c}\text { МКЦ із } \\
\text { Волокон конопель }\end{array}$ \\
\hline Зовнішній вигляд і колір & $\begin{array}{l}\text { Білий або майже білий тонкий } \\
\text { або гранулярний порошок }\end{array}$ & $\begin{array}{c}\text { Однорідний порошок білого } \\
\text { кольору без сторонніх } \\
\text { включень }\end{array}$ \\
\hline Ступінь полімеризації & Не більше 350 & 90 \\
\hline рН водневої витяжки & $5,0-7,5$ & 6,9 \\
\hline $\begin{array}{l}\text { Масова частка води, не } \\
\text { більше, \% }\end{array}$ & 7,0 & 6,0 \\
\hline Вміст сульфатної золи, \% & максимум 0,1 & 0,09 \\
\hline $\begin{array}{l}\text { Масова частка залишкового } \\
\text { лігніну, \% }\end{array}$ & - & 0,11 \\
\hline
\end{tabular}

Висока хімічна чистота та фізіологічна інертність МКЦ в поєднанні з цінними якостями (хімічна стійкість, нерозчинність у воді і органічних розчинниках, відсутність смаку, запаху та забарвлення) дозволяють використовувати одержану мікрокристалічну целюлозу із волокон конопель в якості наповнювача, стабілізатора й емульгатора в харчовій, косметичній та фармацевтичній промисловості. Також конопляну мікрокристалічну целюлозу рекомендується використовувати у виробництві твердих лікарських форм (таблеток, капсул $\mathrm{i}$ гранул) в якості наповнювача, який виявляє зв'язувальні властивості.

\section{Література:}

1. Y.A. Egoshina, L.A. Potselueva (2009). Modern adjuvants in tablet production, Uspekhi Sovemennogo Estestvoznaniya, 10, 30-33.

2. K. Jaenhwan, Y. Sungryul. (2006). Discovery of cellulose as a smart materials, Macromolecules, 39, 4202-4206.

3. M. Laka, S. (2007). Chernyavskava, obtaining microcrystalline cellulose from softwood and harwood pulp, Bioresources, 2, 583-589.

4. V. Barbash, M. Karakutsa, I Trembus. O. Yashehenko, (2016) Development the technology of obtaining microcrystalline cellulose from the hemp fibers, Eastern - European Journal of Enterprise Technologies, 3, 51-56.

5. Vanhatalo, O. Dahl, (2014). Effect of mild acid Hydrolysis parameters on properties of microcrystalline cellulose, Bioresources, 9, 4729-4740.

6. R. Xiond, X. Zhand, D. Tian, (2012). Comparing microcrystalline with spherical nanocrystalline cellulose from waste cotton fabrics, Cellulose, 19, 1189-1198.

7. V. Barbash, I. Trembus, N. Sokolovska, (2018). Performic pulp from wheat straw, Cellulose Chem. and Technol, 7-8, 673-680.

8. Test Methods. Atlanta. Georgia. Tappi press. 2004. 